\title{
'Religion and Nation are One': Social Identity Complexity and the Roots of Religious Intolerance in Turkish Nationalism
}

\author{
*Forthcoming: Social Science History* \\ https://www.cambridge.org/core/journals/social-science-history
}

\author{
Gregory J. Goalwin \\ Department of Sociology, \\ University of California, Santa Barbara \\ Santa Barbara, CA, U.S.A.
}

\begin{abstract}
:
Turkish nationalism has long been an enigma for scholars interested in the formation of national identity. The nationalist movement that succeeded in crafting the Republic of Turkey relied upon rhetoric that defined the nation in explicitly secular, civic, and territorial terms. Though the earliest scholarship on Turkish nationalism supported this perspective, more recent research has pointed to Turkey's efforts to homogenize the new state as evidence of the importance of ethnicity, and particularly religion, in constructing Turkish national identity. Yet this marked mismatch between political rhetoric and politics on the ground is perplexing. If Turkey was meant to be a secular and civic state, why did Turkish nationalist policies place such a heavy emphasis on ethnic and religious purity? Moreover, why did religious identity become such a salient characteristic for determining membership in the national community and for defining national identity? This article draws upon historical research and social identity complexity theory to analyze this seeming dichotomy between religious and civic definitions of the Turkish nation. I argue that the subjective overlap between religious and civic ingroups during the late Ottoman Empire and efforts by nationalists to rally the populace through religious appeals explains the persistence of religious definitions of the nation despite the Turkish nationalist movement's civic rhetoric, and accounts for much of the Turkish state's religiously oriented policies and exclusionary practices toward religious minorities in its early decades.
\end{abstract}

Keywords: Turkey; Nationalism, Religion; Minorities; Social Identity Complexity 


\section{$\underline{\text { Introduction }}$}

In his influential pamphlet laying out the theoretical groundwork for the Turkish nationalist movement, Yusuf Akçura summarized the relationship between religion and nationalism in the Muslim world by explaining "One of the fundamental tenets of Islam is expressed in the saying "religion and nation are one"' (1981). This adage has been nowhere more put to the test than in the Republic of Turkey, the successor state to Akçura's own Ottoman Empire and a nation his work was influential in building. Arising out of the collapse of the Ottoman Empire during World War I, the Turkish nationalist movement has often been considered a paradigmatic case of civic nationalism. The Turkish national project, led by Mustafa Kemal Atatürk, explicitly emphasized a secular western form of society and government, based on equal citizenship for all, relegating religion and ethnicity exclusively to the private sphere. More recent research has challenged this characterization, however, arguing that ethnic, linguistic, and religious ties played a far more important role in the construction of the Turkish nation than previously recognized. Indeed, despite its supposedly inclusive secular and civic character, the foundation of the Turkish nation involved significant acts of discrimination against religious minorities (Clark 2006; Akçam 2012; Suny 2015), part of a larger pattern of ethnic and religious "unmixing" across the region as societies and peoples struggled to react to the fluid and chaotic political situation. This marked mismatch between the official inclusive civic rhetoric of the nation and the focus on exclusive ethnic and religious politics on the ground raises significant questions about the relationship between civic and religious identities in Turkey. If Turkey was meant to be a secular and civic state, why did Turkish nationalist policies place such a heavy emphasis on ethnic and religious purity? Moreover, why did religious identity become such a salient characteristic for determining membership in the national community and for defining national identity? Is it possible to 
reconcile the civic orientation of Turkish nationalist rhetoric with the religious orientation of its national policies? This article draws on insights from social identity complexity theory, a recent theoretical advance in social psychology, to explain much of this seeming dichotomy and the relationship between the ethnic and civic elements of the Turkish nationalist project.

Scholars interested in the construction and maintenance of social and group identities have paid increasing attention to the fact that most individuals are simultaneously members of a variety of social groups. Social identity complexity theory examines the ways in which these various group identities interact, seeking to understand how individuals construct social identities in relation to multiple nonconvergent ingroup memberships (Roccas and Brewer 2002). This perspective argues that it is how those ingroup memberships are subjectively combined that determines the relative inclusiveness of the individual's sense of social identity (Brewer and Pierce 2005). Individuals with high social identity complexity see their groups as mostly distinct, while those with low social identity complexity perceive their groups as largely overlapping and convergent. Most importantly, individuals with high social identity complexity, those able to recognize and accept the nonoverlapping nature of their various ingroups, have been shown to maintain an inclusive and tolerant social identity. Those with low social identity complexity, who perceive multiple overlapping facets of identity as central to their identity, are more likely to be exclusive and intolerant, rejecting those who fall outside the ingroup on any single level of identity (Brewer and Pierce 2005; Schmid et al. 2009).

To this point social identity complexity theory has been tested only quantitatively, in reference to contemporary survey data (Perry and Whitehead 2015; Brewer and Pierce 2005; Roccas and Brewer 2002; Schmid et al. 2009). This theoretical paradigm can nevertheless prove fruitful for qualitative and historical analyses as well. Though historians and historical 
sociologists often lack the robust contemporary survey and interview data upon which social identity complexity theorists have traditionally based their work, historical evidence can provide important insights into the processes of group identity formation. Historical sources can reveal the ways in which politicians and lay people conceptualized their own subjective senses of identity, and the insights of social identity complexity theory can provide a theoretical mechanism to explain the ways in which those conceptions of identity were translated into policies of political and social inclusion and exclusion. Here I draw on historical sources to argue that circumstances during the last decades of the Ottoman Empire created a situation in which religion and national identity were merged in the minds of many Turks. Despite the civic and secular goals of some elite politicians in the new Turkey the legacy of Ottoman social systems, religious polarization during the collapse of the Ottoman Empire, and the actions of nationalist politicians seeking any means of rallying popular support to promote political goals, produced a new national identity with religion at its core and a national community with a low level of social identity complexity. The overlap between national and religious ingroups explains much of the dichotomy between Turkey's inclusive civic rhetoric and religiously exclusionary practice.

\section{Evaluating the Civic and Religious Elements of Turkish Nationalism}

Traditional approaches to the study of nationalism have distinguished two dominant forms of nationalist projects: civic, which place a voluntary association of people at the center of national identification, and ethnic, which emphasize descent and blood relation (Kohn 1944; Smith 1991; Brubaker 1992). Official Turkish nationalism has long been considered the civic type. Kemalism, the nationalist ideology held by those who followed Mustafa Kemal Atatürk, called for an explicitly secular democratic republic (Çağaptay 2006). The Ottoman Empire had a long history of using religious identity as a category for political purpose, and in fact religion 
was often used as a stand-in for ethnic identity. The Turkish nationalist movement explicitly rejected this organization, however, and based the structure of the new Turkish state on the laicité of France (Hanioğlu 2011, 134). Under such a system, religion was no longer to be a powerful force for social organization, and all those who dwelled within the borders of the new Turkish state were to be considered Turkish citizens and, theoretically, members of the new Turkish nation. The goal was to create a new Turkish state and society constructed around a more modern, European form of social organization that could replace the religiously focused, and thus antiquated, Ottoman Empire.

Mustafa Kemal regarded the transition from religious community to secular nation-state to be essential to Turkey's efforts to "live as an advanced and civilized nation in the midst of contemporary civilization" (Ahmad 1993, 53), and secularism became the official policy of the Turkish state. During the first decades of the new Republic of Turkey Kemal and his successors put into place a variety of political and social reforms designed to create a Turkish form of secular state. Turkey abolished the Caliphate and the religiously oriented Ottoman Millet system in 1924, formally dismantling religion's role as a key facet of political life. Within a decade, policies of language reform were created in an effort to further weaken the connection between Turkey and both Islam and its own Ottoman past (Aslan 2007). Simultaneously, the new Turkey established the Diyanet, the Directorate of Religious Affairs "to execute the works concerning the beliefs, worship, and ethics of Islam, enlighten the public about their religion, and administer the sacred worshiping places" (Adanali 2008, 232). In practice, it represented an effort to bring religion under the control of the central government. Such efforts sought to make religious practice a function of the state, and established a distinctively Turkish form of secularism in which religion was state run but rigorously segregated from the practice of government (Tank 
2005). The first Turkish constitution, ratified in 1924, seemed to support this goal and was very careful to note that "The name Turk, as a political term, shall be understood to include all citizens of the Turkish Republic, without distinction of or reference to, race or religion" and continues on by saying "any individual who acquires Turkish nationality by naturalization in conformity with the law is a Turk" (Earle 1925, 89). Religion was, in Atatürk's parlance, to be "relegated to the mosques and consciences" (Uzer 2011, 122), privatized and pushed out of the public sphere in favour of an official secularism that theoretically embraced members of all creeds so long as they accepted the concept of the modern Kemalist nation-state. These provisions and Atatürk's reforms, designed to assert the primacy of the state over religion, testify to the importance of a secular and civic definition of the Turkish nation to the nationalist movement's ideals and ideology.

The earliest wave of scholarship on the Turkish nation supported this rhetoric and tended to portray the development of Turkey as a teleological march from Islamic empire to secular republic (Findley 2010). This wave of scholarship, led by scholars such as Bernard Lewis (1961) and Niyazi Berkes (1964) were heavily grounded in a modernization theory that emphasized the official laicism of the Turkish republic and portrayed Turkey as a dynamic secular and western state. Such works viewed Turkey as a perfect example of one of the prime arguments of modernization and secularization theories, that as societies transition from premodern to modern forms of organization religion declines in importance. This perspective took its cue from the rhetoric of Kemal's secular form of Turkish nationalism, emphasizing primarily the ways in which Turkey had transformed and drawing a stark contrast between the traditional social structure of the defunct Ottoman Empire and the new urbanizing, industrializing, and most importantly secularizing character of the Republic of Turkey. For these scholars Turkey's 
position as a secular civic state was self-evident, and their scholarship was dedicated to exploring the ways in which Turkey had overcome its traditional past and taken its place in the new modern and secular world.

More recent examinations of Turkish nationalism have problematized the characterization of the Turkish state as civic and secular. Rather than presenting a teleological vision of ascending modernization and secularization, these scholars have argued that the development of Turkey as a distinct national community involved a multitude of different strands of nationalist thought, many of which focused far more on ethnic and religious differences than earlier theorists had recognized. Hugh Poulton (1997) identified three distinct impulses operating in the first few decades of the Turkish republic: Kemalist secular western nationalism, a Pan-Turkic ethnic nationalism dedicated to constructing a unified Turkish race encompassing all Turkic peoples, and Islamic variants emphasizing religious identity. Tanil Bora (2003) has further nuanced the picture of Turkish nationalism, arguing that by the 1990s five distinct nationalist discourses - Kemalist, Left-wing, Pro-Western, Pan-Turkist, and Kurdish had found purchase in the Turkish political arena. Other scholars have found similar results, recognizing linguistic (Aydingün and Aydingün 2004), ethnic (Uzer 2011; Gingeras 2009), and religious (White 2013) dimensions of the Turkish national project. This more recent research has thus added significant complexity to our picture of nation building processes in Turkey. It is now clear that despite the nationalist movement's secular and civic focus, ethnicity and religion played a powerful role in the development of Turkish national identity.

Yet this dichotomy, between religious and civic dimensions of Turkish national identity continues to dominate much of the scholarship on Turkish nationalism, in large part because it continues to underlie the fundamental questions of Turkish politics itself (Merdjanova 2014). 
What does it mean to be a Turk? What is the proper role of religion in society? What should be Islam's relationship with the state? Scholars have asked similar questions, given the competing definitions of the Turkish nation and the seemingly disjointed nature of its national policies. How are we to reconcile the ethnoreligious dimensions of Turkish nationalism with the explicitly secular and civic rhetoric that typified the official Kemalist nationalism in Turkey? Ultimately the process of nation building is one of boundary-formation, determining who does and does not qualify for membership in the national community (Wimmer 2013). One approach to understanding the boundaries of Turkishness has been to view the relationship between religion and official nationalism in Turkey as largely instrumental in character, either as a "short term tactical alliance" (Özkirimli and Sofos 2008, 58) between secular and religious nationalists, or as a means of providing social cohesion for an insecure state still struggling to define its own unified identity. This perspective holds promise, providing a plausible explanation for the disjuncture between Turkey's officially secular rhetoric and its policies towards religious minorities in the early years of the Turkish state. Viewing this inconsistency as a short term alliance, however, does not adequately explain the Turkish state's continued reliance on religion as a definitive characteristic of membership in the decades that followed. As Kanchan Chandra has argued, analyses that examine the constructed nature of national groups are many and varied, but few scholars have sought to understand the effects such processes have had on economic and political outcomes (Chandra 2012) Insights drawn from social identity complexity theory, however, can help explain much of this continued emphasis on religion and the concomitant exclusionary treatment of religious minorities throughout much of Turkish history. An emphasis on the underlying processes of boundary formation that defined the Turkish nation, and the ways in which national identity coalesced out of a conflation of religious and political identities 
amongst the majority of the Turkish public, can thus reveal the logic behind continued antipathy towards non-Muslim minorities, and corresponding moves from political figures to exclude them from Turkish political and social life.

\section{Social Identity Complexity Theory}

Social identity complexity is a theoretical construct designed to reflect the relationship between the crosscutting layers of identity that make up an individual's overall conception of self. In essence, a person's degree of social identity complexity refers to the "degree of overlap perceived to exist between groups of which [that] person is simultaneously a member" (Roccas and Brewer 2002). As Roccas and Brewer explain, scholars are most interested "When ingroups defined by different dimensions of categorization overlap only partially... In this case some of those who are fellow ingroup members on one dimension are simultaneously outgroup members on the other $(2002,89)$. Under such circumstances individuals construct their own subjective sense of social identity as they seek to reconcile their relationship to multiple nonconvergent ingroup memberships. Social identity complexity reflects how this reconciliation has been accomplished, the product of a cognitive process by which individuals recognize and interpret information about their own ingroups. "Low complexity means that multiple identities are subjectively embedded in a single ingroup representation, whereas high complexity involves acknowledgement of differentiation and difference between ingroup categories" (Roccas and Brewer 2002, 93) Ultimately, it is the individual's own perception of the relationship between his or her ingroups that is of critical importance. "In sum, the more a person perceives the groups to which he or she belongs as sharing the same members, the less complex is his or her social identity" (Roccas and Brewer 2002, 94). This subjective perception of the relationship between different dimensions of identity plays a powerful role in the ways in which people think about 
their membership in various groups. Individuals with high social identity complexity often conceptualize their social identity in such a way that others who share any salient dimension of identity are considered part of the social ingroup. Conversely, individuals with low social identity complexity often conceptualise their own sense of identity such that others must share all relevant characteristics of identity in order to be considered members of the social ingroup, conflating multiple levels of identity into a single overarching concept of group belonging.

Ultimately, it is the relationship between self and other that lies at the center of these identity processes. Research has shown that the ways in which people conceive of their own ingroups — whether they develop a high or low level of social identity complexity — is affected by a variety of factors. Experience with groups outside of one's own social categories, tolerance for uncertainty and ambiguity and openness to change, for example, have been correlated with a higher degree of social identity complexity and thus a more open concept of group membership. Conversely, little experience of diversity, stress, a need for closure, and ingroup threat have all been found to have a negative effect on social identity complexity as individuals harden the boundaries of their social ingroups (Brewer and Pierce 2005). Research suggests that threat to one's social ingroup represents one of the most powerful influences on perceptions of social identity complexity. Indeed,

When there is a perception of threat, individuals perceive their ingroup as more homogeneous and perceive the self as more similar to the ingroup and more different from the outgroup. (Roccas and Brewer 2002, 99)

These reactions to situational context thus have an important impact, not just on the ways in which individuals present their own self-identity but also on the ways in which they view people who are thought to fall outside the membership of their own ingroup. Studies have shown that individuals with a high degree of social identity complexity are far more likely to be tolerant of 
differences and members of outgroups, recognizing that membership in their ingroups rely upon multiple levels of identification, rather than excluding outsiders out of hand (Brewer and Pierce 2005; Schmid et al. 2009). Individuals with a low degree of social identity complexity, however, are more likely to be intolerant of differences, their multiple layers of identity all reduced to a single expression of the ingroup, outside of which all others are considered different.

\section{Methods and Sources}

This paper departs from previous studies that take a social identity complexity approach by applying it to a historical case, seeking to provide a theoretical explanation for the continued salience of religious definitions of identity in a self-avowedly secular state. Though focusing on a historical case precludes the survey and quantitative approaches used by earlier scholars of social identity complexity to examine nationalism and feelings of group solidarity, a close look at historical evidence can begin to reveal similar processes at work in past movements, thus extending the reach and applicability of social identity complexity theory. Because social identity complexity refers to the subjective ways in which individuals perceive the overlap of group membership in different dimensions of identity, a historical approach needs to examine the ways members of the Ottoman and Turkish population conceptualized their own senses of individual and group identity. Though most studies of the Turkish nationalist movement have focused on official policies and documents often published by Kemalist elites (Brockett 2011a, 14), recent strides have been made in developing a social historical approach to Turkish nationalism, emphasizing the beliefs and perceptions of everyday people as they struggled to come to grips with the radical transformation from Ottoman Empire to Turkish Republic (Brockett 2011b). Such efforts have utilized collections of alternative sources such as provincial newspapers (Brockett 2011a), oral histories (Doumanis 2013) periodicals (Ekmekçioglu 2016), 
and memoires (Göçek 2015), to supplement the official narrative of Turkey’s elite nationalists and provide a more balanced and comprehensive picture of the end of the Ottoman Empire and the founding of the Republic of Turkey. This study follows such trends and utilizes similar sources. Here I draw upon the writings of late Ottoman Muslim bureaucrats and military officers, who were in a position to write about religion, ethnicity, and nationalism. Such sources allow us to examine the ways in which people on the ground spoke and wrote of their own national and group identities and examine what membership in such groups meant to people in their everyday lives.

This article thus looks at a broad spectrum of historical evidence to analyze the relationship between religion, ethnicity, and nation in the Republic of Turkey. In what follows I trace this relationship across roughly sixty years of Ottoman and Turkish history. I begin with an analysis of the turmoil that accompanied the decline and collapse of the Ottoman Empire in the first two decades of the twentieth century. Close analysis reveals that all of the conditions Brewer and Pierce identify as leading to low levels of social identity complexity were present during this time period, leading to a conflation of religion and national identity as Ottoman populations struggled to reconceptualize collective identity. This association was heightened by the polarization of identity that accompanied the collapse of the Ottoman Empire and by the actions of nationalist entrepreneurs, who sought any opportunity to rally the Turkish populace to their political goals, drawing on religious conceptions of the nation even where it conflicted with their own ideological rhetoric. This analysis then continues through the reform period of the 1920s and 1930s, when Turkey sought to consolidate itself as a distinct national community. Here I argue that though a small but powerful Turkish elite sought to craft a secular sense of Turkish identity, the vast majority of the Turkish population continued to subjectively view 
religion and national identity as essentially contiguous in groups. I then finish with an analysis of the pogroms against religious minorities that shook Istanbul in the 1950s, when the conflation of religion and identity burst forth in a display of religiously oriented violence. Such an approach reveals the continued salience of religious dimensions of national and group formation well into the Turkish Republic. In contrast to the official narrative, this analysis shows that the religious considerations that dominated Ottoman society in its last years did not subside with Mustafa Kemal's modernizing reforms. Rather, conceptions of religious, ethnic, and national identity that were fused in early modern times continued to shape ideas of Turkish nationhood long after they were supposed to have disappeared. In turn, these attitudes played an important role in shaping Turkish policy towards religious minorities, who were never truly considered members of the nation by their Muslim Turkish neighbors. I argue that this persistence of religious identification and the intolerant attitudes it engendered can best be understood as the consequence of subjective perspectives of what it meant to belong to the Turkish ingroup, the result of a low level of social identity complexity.

\section{$\underline{\text { Religion and National Identity in Turkey }}$}

The relationship between religion and identity has a long history in Turkey. As Bernard Lewis argued, during Ottoman times "Among the different peoples who embraced Islam, none went farther in sinking their separate identity in the Islamic community than the Turks" (1961: 329). Religion had indeed played a powerful role in life under the Ottoman Empire, where the population was divided into distinct millets based on religious identity. Strict lines were drawn in a variety of social and political spheres, dividing the rights and responsibilities of non-Muslim subjects of the Ottoman Empire from their Muslim counterparts (Bayar 2014: 18). In this, the millet system codified and made political a social system in which religious difference served to 
structure daily life within the multicultural and multireligious Ottoman polity. This emphasis on religion would play an important role during the rapid political and social changes that accompanied the Ottoman Empire's collapse, as religion quickly became a metonym for larger issues of national belonging. Indeed, a close look at the political and social context of the late Ottoman Empire and early Republic of Turkey reveals all of the conditions Brewer and Pierce identify as being factors in the development of group identities that equate social categories, characteristics such as religion and national identity, into a single overarching sense of collective identity that demonstrates a low sense of social identity complexity.

\section{Experience of Diversity}

Despite its multiethnic and multireligious character, late Ottoman society remained highly segregated, and many Ottoman Turks would have had little experience with diversity. As Ronald Suny has argued, in big cities such as Istanbul or Smyrna "Their social interactions were primarily with people in their own millet rather than with those outside with whom they were unlikely to worship or marry or even bathe in the same hamam. Members of Ottoman minorities developed social interactions with other non-Muslims or with Europeans resident in the larger cities" (Suny 2015, 46). Religious communities jealously guarded intergroup boundaries and though commerce and fellowship were shared across religions, conversion, mixed marriage, and other forms of cultural blending were relatively rare. The strict enforcement of group boundaries was the result of the ways in which self and communal identity was conceptualized in the Ottoman Empire. Such concerns structured the ways in which people perceived of their identity. For many in the Ottoman Empire the religious facet of identity was so dominant that ethnic and national categories of identification "meant little to the people in question. Western accounts 
often refer to Balkan peasants who seemed puzzled by the ethnic labels ascribed to them," (Doumanis 2013, 16) a condition not uncommon in other areas of the Ottoman Empire as well.

\section{Uncertainty, Stress, and Need for Closure}

The collapse of the Ottoman Empire and its transition to the Republic of Turkey represented an immensely uncertain time for residents of Turkey as social, political, and cultural structures were torn down and reformed. Pressures accompanying this transition pushed a reconceptualization of self and group identities for many Turks. This reformulation was the result of events on the world stage. The rise of nationalism in Western Europe spread quickly to the east, and Christian populations in the Balkans rose up against the Ottoman Empire. Internal turmoil and the failure of much needed efforts at reform weakened the Ottoman Empire significantly, and in 1912 and 1913 Bulgaria, Greece, Montenegro, and Serbia forged a successful alliance that stripped the Ottomans of most of their European territories. The violence that accompanied the Ottoman Empire's loss of its European colonies brought with it a wave of human misery as communities were polarized by national conflict expressed in religious terms. The Balkan Wars entailed significant amounts of ethnoracially motivated violence and terror, an ethnic, and therefore religious, "unmixing" of populations that had been lived in close proximity for centuries (Brubaker 1995). Millions of Muslim refugees fled the Balkans for safer conditions deeper within the Ottoman Empire, providing a highly tangible symbol of Ottoman decline and collapse for many rural Anatolians, who lived far from the fighting and centers of power, but now came face to face with their civilization's impending mortality. 
The influx of Muslim refugees from the Balkans and the perceived demise of the Empire polarized Ottoman society. Religious identities, which had long been markers of relatively benign difference acquired an increasingly political charge. Increasingly, religion became a powerful defining line between those considered loyal to the nation and those perceived to be a threat. Contemporary accounts reveal the escalating level of despair among Ottoman Muslims as they watched their coreligionists suffer and encountered at first hand the victims of Christian atrocities. One account explains that the escalating series of crises facing the Empire made it feel as if "A nation was disintegrating, sinking into the darkness of history" (Göçek 2015, 189). This sense of catastrophic decline led to significant levels of uncertainty, stress, and a need for social closure amongst Muslims in the Ottoman Empire. It became increasingly evident to politicians and lay people alike that the Ottoman system had failed, and that a new form of social organization would need to take its place. Yet this growing realization brought with it yet more stress as Ottoman Muslims recognized the potential danger to their cultural and political hegemony that a radical revolution of social structure might entail.

\section{Ingroup Threat}

The Ottoman Empire's collapse created significant levels of ingroup threat for

Ottoman Muslims. Christians in the Balkan nations used their victory in the Balkan Wars as an opportunity to pay back the Ottomans for what they saw as centuries of oppression. Such ethnically and religiously targeted violence had vast repercussions. The Muslims who arrived in Anatolia brought with them heartbreaking stories of Christian campaigns of brutality and ethnic cleansing against Muslims. Intercommunal tensions in Anatolia, already strained by the outbreak of war and the perceptible decline of the Ottoman 
Empire, ratcheted ever higher. Oral histories from the time reveal the damage such violence did to intercommunal relationships as Muslims responded to what they perceived to be an existential threat from their Christian neighbors. As one Anatolian Christian related, before this time period "The Turks did not pressure us. We loved them, they loved us. But the Macedonian Turks came through here and they were fanatics and they spoiled them.” (Doumanis 2013, 140) Another argued that

The Turks were good people. Only after 1912 did our relations with them suffer, for the Turkish refuges from Macedonia and Crete would say "they've pushed us out." They'd say [to the Anatolian Turk], "hey you. You have THESE people as your 'brothers'? Do you realize what the Greek army did to us?" (Doumanis 2013, 140)

Such sentiments were shared by Muslim Turks, one of whom explained that "The deadly news delivered by the convoys of [Balkan] migrants poisoned us" (Amça 1958, 118). Not only did the influx of Muslim refugees turn the sentiments of Anatolian Muslims against their neighbor Christians, the increasing polarization of identity and anti-minority sentiments extended to physical violence as Muslims driven from their homes in the Balkans extracted revenge against Christians in their new land. As official campaigns against Christians in Anatolia got under way, Muslim Turkish refugees began "to slowly show the Greek Rum the torture they themselves had suffered in the Balkans" (Sunata 2003, 72-73).

The situation was made much worse less than a decade later, when the Ottoman Empire was defeated in World War I. The Sultan's capitulation heralded the breakup of the remains of the Ottoman Empire and the Treaty of Sèvres granted significant Ottoman territories, including massive stretches of Anatolia itself, to the victorious Western powers. Among the most difficult of these to bear was the granting of Smyrna (now Izmir) and its surrounding territories to Greece. The Greek army occupied Smyrna in May of 1919 and used the city as a staging point for an 
invasion that pushed deep into Anatolia. When the Greek army landed in Smyrna it was met with celebration by many of the Greek residents of the town. The invading Greek army, its leaders and soldiers steeped in the sort of nationalist ideology that drew strict boundaries between Christian 'Greeks' and Muslim ‘Turks,' committed savage atrocities against the Muslim populations they found in Anatolia. Western sources relate countless reports of the Greek army's violence against civilian populations. The Greek landing itself turned into a slaughter when the Greek army opened fire on the surrounding Turkish population killing several hundred "beastly and wildly," in the words of an Italian naval officer who beheld the scene ( Erhan 1999, 7). The depredations were not confined to Smyrna, however. As the Greek army consolidated its control, Greek soldiers and the local Greeks who were "incited by the Greek officers and clergy, committed innumerable atrocities against the Turks" in surrounding villages (Erhan 1999, 8). Conditions only deteriorated from there, as both the Greek army and the revolutionary Turkish government utilized paramilitary forces who carried out campaigns of interreligious violence until the Greek army, routed by a Turkish defense outside of Ankara fled west, and were joined by much of the Greek Orthodox Christian population of Anatolia, now fearful of their fate under an explicitly Muslim society, as they returned to Greece. Turkish accounts of the invasion later published in the region's newspapers explicitly emphasized the religious characteristic of the national schism, reinforcing again, the centrality of Islamic belief to the new nation (Morack 2017).

\section{Religion and the National Movement}

The social and political context that accompanied the Ottoman Empire's collapse thus created conditions that made religion a natural unifying force for the new national movement. Indeed, the subjective conflation of religious and ethnic identity, that most people conceptualized 
religion as determining ethnicity, drove many of the nationalist movement's policies as they sought to rally popular support for the cause. This effort to construct and define a new sense of Turkish identity and selected key characteristics around which Turkish nationhood could form is explicitly visible in the work of Turkey's earliest nationalist thinkers. Yusuf Akçura and Ziya Gökalp, considered two of the most important theorists of Turkish nationalism, both devoted significant attention to this question, seeking to determine the proper relationship between civic, religious, and ethnic dimensions of identity in the new Turkish nation. In his 1904 "Three Kinds of Policies" Akçura discussed the change in focus amongst early nationalists from an Ottomanist civic version of the nation, in which Muslims and non-Muslims would share membership in the nation to one emphasizing Islamic or ethnic Turkic identity as key signifiers of membership in the national ingroup. Akçura argued that earlier efforts to create a civic form of Ottomanism had been unsuccessful because reformers "had failed to grasp the significance of race and religion" $(1981,7)$. Akçura argued that once it became obvious to the Ottoman reformers that religious minorities could not be adequately assimilated into the Ottoman nation, nationalist opinions toward them hardened. These attitudes resulted in hostility towards Christians, viewing them as outsiders $(1981,8)$. Indeed, Akçura saw only one inevitable result of this sort of approach "the religious discord and enmity among Ottoman subjects would accentuate, and the non-Muslim subjects and the areas in which they constitute a majority would be lost" $(1981,15)$. Though the "Ottoman nation" would be temporarily weakened in such an eventuality "it would, for all its shortcomings... give rise to a stronger community, an Islamic community" $(1981,16)$. Such a decrease in religious and ethnic diversity, though crafting a more homogenous society in the way Akçura preferred, also furthered the segregation of society. Individuals in the last decades of the Ottoman Empire experienced less contact with those who fell outside of the boundaries of their 
own highly conflated social ingroups, providing less opportunity to acknowledge multiple crosscutting dimensions of identity, and fostering a sense of national identity that heavily emphasized ethnicity and religion, rather than Ottoman multiculturalism.

Though Akçura himself advocated Turkish race and ethnicity as the proper foundation for the new Turkish nation, he recognized the role that Islam should play in the formation of national identity. "It should not be forgotten" he argued "that the greater part of the Turks whose unification is envisaged are Muslims. From this point of view, the Islamic religion can be an important element of a great Turkish nation" (Akçura and Fehmi 1981, 18). The creation of a new specifically Turkish nation was thus, to Akçura, a complex process. What we see in his discussion of Turkish nationalism, however, is the failure of a secular and civic minded form of Ottomanism in favour of a more ethno-religiously focused conception of the nation, an entanglement of national and religious modes of identity. Critically, Akçura represents ethnic, religious, and national identities as being multiple facets of a single Turkish ingroup. To be a "true" Turk meant holding allegiance to the state, sharing Turkish blood, and practicing a distinctly Turkish form of Islam. Those who failed on any dimension could not truly be considered members of the Turkish nation.

Ziya Gökalp, made a similar argument about the role of religion in the Turkish nation. Gökalp, unlike Akçura, argued that it was Turkish culture, not race or ethnicity that should define the new Turkey. In his 1923 The Principles of Turkism Gökalp argued that an emphasis on ethnic purity is normal for nations in the early stage of social evolution, but was "pathological" for the stage Turkey had reached. Instead, at the current stage "social solidarity rests on cultural unity, which is transmitted by means of education and therefore has no relationship with consanguinity" $(1968,13)$. Gökalp argued that it is clear that a nation is not a 
racial, ethnic, geographic, or political group "but one composed of individuals who share a common language, religion, morality, and aesthetics." After all, he continues "In truth a man desires more to live with those who share his language and religion than with those who share his blood, for the human personality does not dwell in the physical body but in the soul" (1968, 15-16). Here too, Gökalp placed a key emphasis on the role of religion in promoting national identity and solidarity. To Gökalp, in order to form a true community a modern state must become homogenous in terms of culture and religion, and thus national identity (Akçam 2006, 88). Gökalp's vision of the Turkish nation was thus a community that would share a common culture, defined explicitly in terms of language and religious identity. Here again, belonging on multiple levels of identity was considered crucial for true Turkishness. The vision of Turkishness that Gökalp preached conflated religion, language, morality, and even aesthetics, a singular national ingroup, revealing a low sense of social identity complexity. Those who fell outside of the boundaries of the new community on any single dimension of identity could not adequately conform to Turkish culture, Gökalp's main point of emphasis, and thus did not qualify as members of the new overarching concept of Turkish identity being developed by the nationalist movement.

Despite its professed civic character, the growth of Turkish nationalism would rely significantly on Gökalp's theoretical approach to the Turkish nation (Parla 1985, 7). The Kemalist emphasis on the confluence of linguistic community, culture, and Turkified Islam were the culmination and extension of pre-existing processes first theorized and set in motion by late Ottoman thinkers (Dumont 1984, 30). In his Nutuk, the great speech recounting, and in many ways formulating the official history of, the Turkish nationalist revolution, Mustafa Kemal himself drew on popular conceptions of religious identification. Kemal explicitly discusses the 
danger of the collapsing Ottoman Empire's Christian minorities. In the speech Atatürk describes how after the defeat of the Ottoman Empire in WWI and the occupation of various parts of its territory "Christian elements were also at work all over the country, either openly or in secret, trying to realize their own particular ambitions and thereby hasten the breakdown of the State" (Atatürk 1980, 1) Elsewhere, Kemal described the religious dimension of the struggle for independence, arguing that "God's help and protection are with us in the sacred struggle which we have entered upon our fatherland and independence" (Atatürk 1980, 513).

Other nationalists, too, relied upon religion in public statements describing Turkish identity. In an address to the Lausanne convention in which he discussed the situation of minorities in Turkey İsmet İnönü, lead Turkish negotiator and the general who led the victorious campaign over the Greek army in the Turkish War of Independence, described the debate over Christian minorities in Turkey as a historical problem, a primordial clash of civilizations dating all the way back to the Turkish conquest of Constantinople in 1453. İönü proceeded to lay out at length the ways that Tsarist Russia and other Christian powers had interceded in Turkish affairs, instigating and supporting various heinous rebellions by Christian populations who had previously been content to live in peace under the beneficent leadership of the Turkish (Ottoman) state. İnönü summed up by arguing that in light of such continued foreign interventions on behalf of Christian minorities, and the tendency of those minorities, once instigated, to rebel violently, an enforced population exchange was necessary for the security and development of both the minorities, and Turkey itself (Great Britain 1923, 190-204). In its decision to privilege religious and ethnic dimensions of identity over the civic and secular dimensions of identity endorsed by its own rhetoric, the Turkish nationalist movement helped construct a Turkish national identity with a low level of social identity complexity. Those who could meet the new definition of 
national identity on multiple levels of identity — ethnicity, race, language, and religion — would be welcomed into the new national ingroup and be considered "true" Turks. Those who fell outside the ingroup on any of these dimensions were regarded with suspicion and thus were not truly Turks in the most important senses of the term.

\section{The Politics of Exclusion}

Faced with constructing a new national community, Turkish nationalists, even those who preferred a more secular system of government, were more than willing to go along with the use of Islam as a cultural component on which to found a national identity. Indeed, with the new state's obsession with defining boundaries, the violence that Akçura foresaw and the homogenization that Gökalp thought necessary were not long in coming. As the new Turkish nation struggled to resist the imperialist ambitions of western powers and form a new nation out of the wreckage of the Ottoman Empire, attention swiftly turned to the question of minorities within Turkish territory. The Turkish government undertook significant efforts to assimilate all Muslim minorities who were not ethnically Turkish. The government initially attempted to rely on shared bonds of religion to form a bond with the Kurds, for example, desisting only when it became obvious that Kurdish social structure would prove too resilient for such efforts (Yavuz 1998; Poulton 1997; Belge 2011). Indeed, the Turkish government targeted all Muslim minority groups for assimilation, with varied success, as the state sought to craft a new ethnically and religiously pure nation.

Such was not to be the case of non-Muslim minorities, however. Viewing such populations as traitors and potential fifth-columns within the new nation, the Turkish government took severe measures to deal with what they considered a significant threat. Again, the potential of ingroup threat provided a powerful motivation for hardening ingroup boundaries 
and adopting a more strictly limited, and thus less complex, conception of social identity (Brewer and Pierce 2005). Turkish nationalists were quick to respond to the threat. Hüseyin Cahit Yalçin, a journalist who often expressed the opinions of the ruling Committee of Union and Progress (CUP), summarized their approach to Christian minorities by saying "For the State... [and] the Constitutional Regime, the greatest danger came from the non-Turkish elements within Ottoman Society" thus "the history of the Constitutional period is the history of the Turks, who perceived the danger, and struggled not to drown in the flood of peoples" (Akçam 2006, 56). Such efforts to stem the tide of minority peoples began before even the formal founding of the nation, with the Armenian Christian population in Eastern Anatolia. While estimates vary, somewhere between 800,000 and 1.5 million were massacred in the Armenian Genocide. Throughout, the Turkish nationalist movement's concern was for the homogenization of the Turkish homeland, removing a minority population that did not share Turkish culture or religion. As influential CUP member Halil Menteşe argued "Had we not cleansed our Eastern Provinces of Armenian revolutionaries collaborating with the Russians, there would have been no possibility of establishing our national state" (Akçam 2006, 122). Here again, religion was seen as an integral part of Turkish culture and identity, ethnic, religious and national identities were conflated in a way that strictly delineated in and outgroups. To be a Turk meant being a Muslim, a relationship which displayed a very low degree of social identity complexity.

Similar motivations lay behind the 1923 population exchange between Greece and Turkey. Though the Turkish nationalist movement managed to repel the Greek invasion and retake western Anatolia, Greece and the Greek Orthodox population that remained in Turkish territory were seen as a dangerous threat to the nascent Turkish nation. Again, Turkey took steps to deal with this threat directly, this time in concert with Greece and the Allied powers. Under 
the terms of the Convention Concerning the Exchange of Greek and Turkish Populations - an agreement reached during the negotiations that established the Republic of Turkey — the remnants of the some 1.3 million Anatolian Greek Orthodox Christians, were exchanged for 400,000 Muslims living in Greece, (Clark 2006, 12). Theoretically designed to 'unmix' national populations, this exchange is a particularly useful example of the degree to which religious and national identities continued to be fused in the newly forming Turkey. The exchange explicitly utilized religious affiliation as a proxy for national identity, assuming that anyone who was Orthodox Christian could not be Turkish and Muslims could not be Greek. While the politicians involved expressed reluctance and regret over the compulsory nature of the exchange, it was clear that many thought the exchange was the only way to calm tensions in an area claimed by both states (Clark 2006, 54). The exchange was thus meant to homogenize both countries and remove "dangerous" minority elements that threatened the fledgling self-constructed historical narratives and national identities of the two states (Yildirim 2006b). The concerted effort to remove all Christians from the new Turkey that accompanied this exchange (Ladas 1932) reveals the significance with which the nationalist government invested the question of religion. It was of critical importance to many of the Turkish leaders that the new Turkey be an exclusively Muslim state, free of the Christian minorities that had proved problematic to the Ottoman Empire in the past and might conceivably do the same for the new Republic of Turkey in the future.

Crucially, despite the civic character of the rhetoric of the new Turkish nation, populations were exchanged even when all other markers of identity — characteristics such as language, ethnicity, and territorial origin — ran contrary to their religious affiliation. As one first-hand account phrased it "We were trying by force to remove these Greek Rum elements that had been almost completely Turkified" (Ulunay 1999, 100). This was particularly true of the 
Karamanli people of central Anatolia, for example, a Turkish-speaking group of Greek Orthodox Christians who Turkey made part of the exchange, despite expectations that they would be allowed to remain in place (Balta and Kappler 2010). Orthodox Arabs from Cilicia were similarly compelled to emigrate to Greece despite their lack of any connection with Greece or with Hellenic nationalist sentiments (Ladas 1932, 379-83). On the other side of the exchange Muslims from Greece, who despite their centuries of ancestral roots in Greece and lack of any understanding of the Turkish language were sent to Turkey, where their religious identity more closely matched that of surrounding population in their new ethnic "homeland" (Yildirim 2006a, 59). Tellingly, Greek Muslims that were relocated to Turkey during the exchange often faced significant discrimination for their inability to speak Turkish (Kolluoğlu 2013). Though their religion was now appropriate, they still did not fulfill all the requirements to be considered part of the new Turkish ingroup, lacking "Turkishness" in the linguistic dimension, and thus not immediately considered members of the new Turkish nation.

This conflation of religious and national identity lasted well past Turkey's founding period, however. As Turkey entered the high Kemalist years of the 1930s, religion continued to play a powerful role in defining national identity. As Soner Çağaptay has argued, this was particularly true in regards to immigration policy, where Turkish policy utilized religion as a litmus test when granting citizenship and allowing entrance to the country (2006, 65). Turkey allowed some of the remaining Greeks in Istanbul to gain full citizenship rights if they were willing to convert to Islam (Çağaptay 2006, 75). Similarly, Turkey allowed wide scale immigration of Muslims from former Ottoman territories while denying entrance to Christians from similar territories and denaturalizing minority residents of Turkey who had left during the wars. As a resettlement law adopted in 1926 explained "Those who don't share the Turkish 
"hars"... will not be admitted as immigrants"(Çağaptay 2006, 85). The Turkish word, "hars," means culture, and is the same word Gökalp used to refer to Islam and a shared sense of cultural identity in his own efforts to define the Turkish nation. At the beginning, Turkey explicitly utilized religious terms in citizenship decisions, specifically describing those allowed citizenship as "Muslims". This slowly changed throughout the 1930s as the term "Turk" began to replace "Muslim" in the official documents (Çağaptay 2006, 78). Significantly, while the term used to describe such immigrants changed, immigration policy itself did not. Citizenship and immigration priority was still determined on religious grounds, but the relationship between religion and national identities was such that the terms were interchangeable, members of the Muslim ingroup and members of the Turkish ingroup were considered one and the same, and those that fell outside of the Muslim ingroup could not and would not be Turks.

Other policies put in place by the Turkish government reveal an emphasis on religion in determining full membership in the nation. A law passed in 1931 established strict control of the press in Turkey, permitting only Turks to own magazines or journals ("Matbuat Kanunu [The Press Law]" 1931). Similarly, a Law on Associations was passed in 1936 prohibiting the establishment of organizations and associations representing ethnic and religious minorities (“Cemiyetler Kanunu [Law on Associations]" 1983). Most devastatingly, law number 2007 passed in 1932 banned non-Turkish citizens from a large variety of professions, both skilled professional ones and those requiring little formal training (“Türkiye'de Türk Vatandaşlarina Tahsis Edilen Sanat ve Hizmetler Hakkinda Kanun [Law on Professions and Services Allocated to Turkish Citizens in Turkey. Nr, 2007" 1932). This law was aimed specifically at the remaining Greek Orthodox population in Istanbul, which had been exempted from the population exchange and remained a thorn in the side of Turkish efforts at homogenization. As Çağaptay explains, 
many of these Greek Christians were left unemployed, and more than 15,000 left the country as a result $(2006,70)$. The burdens on the remaining religious minorities were made even heavier in 1942 when under the pretence of raising funds for national defence, the Turkish government imposed a strict tax on non-Muslim citizens, a move widely understood to be an effort aimed at financially ruining the remaining non-Muslim minorities in Turkey (Çetinoglu 2012, 14; Ince 2012, 75). Though this tax was nominally to be paid by all residents of Turkey the rates imposed were extremely unequal, placing a far heavier burden on non-Muslims while taxing Muslims at an insignificant level.

Discrimination and mistreatment of the remaining religious minorities in Turkey extended beyond official government policy, however and in September 1955 hostility towards Christians and Jews boiled over in violent riots targeting non-Muslims in Istanbul. Following the explosion of a bomb outside Atatürk's historic house in Salonika, later proved to have been planted by the Turkish Secret Service, thousands of shops, homes, churches and cemeteries owned by Christians were burned and destroyed (Kuyucu 2005, 362). Rioters caused nearly $\$ 300$ million worth of damage to Christian and Jewish property, with Greek Orthodox Christians in Istanbul serving as the primary target (Göçek 2015, 259). Anecdotal accounts and later research have argued that the Turkish government played a powerful role in planning and directing the riots (Vryonis 2005). Some scholars have argued that the pogrom that resulted was a reflection of rising tensions over control of Cyprus and served as retaliation for Greek Cypriot attacks on Turkish Muslims there (Dosdoğru 1993), while others have seen it as a means to disadvantage remaining Christian populations whose continued presence and prosperity had been a symbolic thorn in the Turks' side since the Treaty of Lausanne in 1923 (Kuyucu 2005). Whether the result of such deeper motivations, or as a spontaneous outpouring of outrage as a result of the bombing, 
as others have maintained (Fersoy 1979) there is little doubt that the tens of thousands of exclusively Muslim Turkish rioters who targeted non-Muslim churches, homes, and schools did so out of a belief that non-Muslims were not full members of the national community. As one bureaucrat later related in his memoirs, after the riots he found his colleagues "immersed in newspapers, reading on the one side, looking at the pictures on the other, saying things like 'it is a good thing this happened; it was necessary; these rotten bastards had gotten too big for their britches; it was time to teach them a lesson"” (Oğuz 2000).

\section{Conclusions}

When Yusuf Akçura related the old adage that in Islam "religion and nation are one" he did so critically, arguing that though it was a formulation all Muslim children learned while they were young, attempts in his time to reconceptualize the fading multireligious and multicultural Ottoman Empire as a modern nation through pan-Islamism and an emphasis on religion were destined to fail. Atatürk's secularizing reforms seemed to confirm such an opinion, and scholars have long argued that they spelled an end for religious definitions of communal identity and the rise of a civic and secular nation. A historical examination of the ways in which Turks have viewed the role of Islam in the modern nation reveals that, contrary to the civic rhetoric expressed by the Kemalist movement, the maxim that Akçura discounted has, in fact, held true: Turkish self-conceptions of national identity have frequently been intimately intertwined with membership in the Islamic community. From the very beginning of the nation, Turks have subjectively perceived a high degree of overlap between members of the Turkish nation and adherents of Islam. Analysis of nationalist theorizing, political actions, and treatment of religious minorities reveals that for many Turks, to be a full member of the Turkish nation meant to be a 
Muslim; those who were not a member of the religious community were simultaneously excluded from the national ingroup.

Here, historical analysis has revealed that social and political conditions during the last decades of the Ottoman Empire were ripe for creating what Roccas and Brewer have called a low level of social identity complexity, that is distilling a variety of facets of identification down to a single hardened and exclusionary ingroup. For residents of the former Ottoman Empire, religion became synonymous with national identity, and all those who fell outside the boundaries of the religious ingroup simultaneously faced exclusion from the national community. This association of religion with nationalism was heightened both by the polarization of religious and political identities that accompanied the Balkan Wars and the collapse of the Ottoman Empire, as well as the actions of nationalist entrepreneurs such as Yusuf Akçura, Ziya Gökalp, and even Atatürk himself, who seized on a religious definition of the nation as a common core around which a new polity could be constructed. The association of religious and national identity had unforeseen consequences for nationalists, however, many of whom were essentially secularist in their own orientation. Conditioned to thinking about the nation in religious terms, indeed with a new national community whose membership was explicitly defined religiously, Turkish politicians and common people alike took steps to reinforce the boundaries of Turkish identity by working to assimilate Muslim ethnic minorities and excluding non-Muslims. Such exclusionary tactics can be seen as the end result of a politics driven by conceptions of social identity that conflate religion, ethnicity, and nation into a single ingroup around which national identity has coalesced.

The Turkish case provides an important example for the efficacy of social identity complexity theory in explaining modern and historical cases of discriminatory politics. Turkey is hardly unique in its paradoxical approach to nationalism, in which exclusionary policy making 
on the ground did not live up to the lofty rhetoric its officially civic nationalism promised. Social identity complexity theory can explain some of this disconnect, bringing into sharper focus the interplay between facets of identification, be they religious, ethnic, national, or other, as well as the negotiations between popular conceptions of identity and the official policies enacted by governments that do not always conform with widespread public consensus. In the Turkish case, elite efforts towards secularization were hindered by the overwhelming emphasis placed on religion in the late Ottoman Empire, and the religious character of the state that reformed from its wreckage. A social identity complexity approach which emphasizes the relationship between the multiple facets of national identity can thus provide important insights into cases in which recalcitrant ethnic and religious definitions of national identity inspire intolerance toward minority populations. In such cases the desire for a civic nation-state amongst portions of the nationalist population may not be enough to create the sort of tolerant and open state civic nationalism supposedly promotes. Instead, in societies which harbour low levels of social complexity, a large subjective overlap between different facets of identity may still lead to a focus on more restrictive definitions of the national community and significant levels of religious and ethnic intolerance as the dominant majority hardens its ingroup boundaries. 


\section{$\underline{\text { Works Cited }}$}

Adanali, Ahmet Hadi. 2008. "The Presidency of Religious Affairs and the Principle of Secularism in Turkey." Muslim World 98 (2/3).

Ahmad, Feroz. 1993. The Making of Modern Turkey. London; New York: Routledge.

Akçam, Taner. 2006. A Shameful Act : The Armenian Genocide and the Question of Turkish Responsibility. New York: Metropolitan Books.

- 2012. The Young Turks' Crime against Humanity: The Armenian Genocide and Ethnic Cleansing in the Ottoman Empire. Princeton, N.J.: Princeton University Press.

Akçura, Yusuf, and Ismail Fehmi. 1981. "Yusuf Akçura's Uç Tarzi Siyaset ('Three Kinds of Policy')." Oriente Moderno 61 (1/12): 1-20.

Amça, Hasan. 1958. Doğmayan Hürriyet. Istanbul.

Aslan, Senem. 2007. "CCitizen, Speak Turkish!': A Nation in the Making.” Nationalism and Ethnic Politics 13 (2): 245-72.

Atatürk, Mustafa Kemal. 1980. Nutuk. 2 vols. Ankara: Kültür Bakanligi.

Aydingün, Ayşegül, and Ismail Aydingün. 2004. "The Role of Language in the Formation of Turkish National Identity and Turkishness." Nationalism and Ethnic Politics 10 (3): 41532.

Balta, Evangelia, and Matthias Kappler, eds. 2010. Cries and Whispers in Karamanlidika Books: Proceedings of the First International Conference on Karamanlidika Studies (Nicosia, 11th-13th September 2008). Wiesbaden: Harrassowitz.

Belge, C. 2011. "State Building and the Limits of Legibility: Kinship Networks and Kurdish Resistance in Turkey." International Journal of Middle East Studies 43 (1): 95-114.

Berkeş, Niyazi. 1964. The Development of Secularism in Turkey. Montreal: McGill University Press.

Bora, Tanil. 2003. "Nationalist Discourses in Turkey." South Atlantic Quarterly 102 (2/3).

Brewer, M. B., and K. P. Pierce. 2005. "Social Identity Complexity and Outgroup Tolerance." Personality \& Social Psychology Bulletin 31 (3): 428-37.

Brockett, Gavin D. 2011a. How Happy to Call Oneself a Turk: Provincial Newspapers and the Negotiation of a Muslim National Identity. Austin: University of Texas Press. . 2011b. Towards a Social History of Modern Turkey: Essays in Theory and Practice. Osmanbey, Istanbul: Libra Kitapçilik ve Yayincilik.

Brubaker, Rogers. 1992. Citizenship and Nationhood in France and Germany. Cambridge, Mass.: Harvard University Press.

. 1995. "Aftermaths of Empire and the Unmixing of Peoples: Historical and Comparative Perspectives." Ethnic and Racial Studies 18: 189-218.

Çağaptay, Soner. 2006. Islam, Secularism, and Nationalism in Modern Turkey: Who Is a Turk? London; New York: Routledge.

“Cemiyetler Kanunu [Law on Associations].” 1983. In TBMM Zabit ceridesi, 26:412-17. V. Ankara: Büyük Millet Meclisi.

Çetinoglu, Sait. 2012. "The Mechanisms for Terrorizing Minorities: The Capital Tax and Work Battalions in Turkey during the Second World War." Mediterranean Quarterly 23 (2).

Chandra, Kanchan. 2012. Constructivist Theories of Ethnic Politics. New York: Oxford University Press.

Clark, Bruce. 2006. Twice a Stranger: The Mass Expulsions That Forged Modern Greece and Turkey. Cambridge, Mass.: Harvard University Press. 
Dosdoğru, M. Hulusi. 1993. 6/7 Eylül Olaylari. Cagaloglu, Istanbul: Baglam.

Doumanis, Nicholas. 2013. Before the Nation: Muslim-Christian Coexistence and Its

Destruction in Late Ottoman Anatolia. Oxford: Oxford University Press.

Dumont, Paul. 1984. "The Origins of Kemalist Ideology." In Atatürk and the Modernization of

Turkey, edited by Landau, Jacob. Boulder, Colo.; Leiden, the Netherlands: Westview

Press ; E.J. Brill.

Earle, Edward Mead. 1925. “The New Constitution of Turkey." Political Science Quarterly 40 (1): 73-100.

Ekmekçioglu, Lerna. 2016. Recovering Armenia: The Limits of Belonging in Post-Genocide Turkey.

Erhan, Çağri. 1999. Greek Occupation of Izmir and Adjoining Territories: Report of the InterAllied Commission of Inquiry (May - September 1919). Ankara: Ministry of Foreign Affairs Center for Strategic Research.

Fersoy, Orhan Cemal. 1979. Devlet ve Hizmet Adami Fatin Rüstü Zorlu.

Findley, Carter V. 2010. Turkey, Islam, Nationalism, and Modernity: A History, 1789-2007. New Haven, CT; London: Yale University Press.

Gingeras, Ryan. 2009. Sorrowful Shores: Violence, Ethnicity, and the End of the Ottoman Empire, 1912-1923. Oxford; New York: Oxford University Press.

Göçek, Fatma Müge. 2015. Denial of violence: Ottoman past, Turkish present, and collective violence against the Armenians, 1789-2009.

Gökalp, Ziya. 1968. The Principles of Turkism. Translated by Robert Devereaux. E.J. Brill.

Great Britain, Foreign Office. 1923. "Lausanne Conference on Near Eastern Affairs 1922-1923: Records of Proceedings and Draft Terms of Peace." London: H.M.S.O.

Ince, Basak. 2012. Citizenship and Identity in Turkey: From Atatürk's Republic to the Present Day. London; New York: I.B. Tauris.

Kohn, Hans. 1944. The Idea of Nationalism: A Study in Its Origins and Background. New York: Macmillan Co.

Kolluoğlu, Biray. 2013. "Excesses of Nationalism: Greco-Turkish Population Exchange." Nations and Nationalism 19 (3): 532-50.

Kuyucu, Ali Tuna. 2005. "Ethno-Religious 'unmixing' of Turkey: 6-7 September Riots as a Case in Turkish Nationalism." Nations and Nationalism 11 (3): 361-80.

Ladas, Stephen P. 1932. The Exchange of Minorities; Bulgaria, Greece and Turkey. New York: Macmillan.

Lewis, Bernard. 1961. The Emergence of Modern Turkey. London, New York: Oxford University Press.

"Matbuat Kanunu [The Press Law].” 1931. In Düstur (Code of Laws), 12:369, 366-80. Third Set. Ankara: Türkiye Büyük Millet Meclisi.

Merdjanova, Ina. 2014. "Secularism, Nationalism, and Minorities in Turkey: Beyond the Myth of Tolerance." Journal of Religion in Europe 7 (3-4): 301-8.

Morack, Elinor. 2017. "Fear and Loathing in 'Gavur' Izmir: Emotions in Early Republican Memories of the Greek Occupation (1919-22)." International Journal of Middle East Studies 49 (1): 71-89.

Oğuz, Burhan. 2000. Yaşadiklarim, Dinlediklerim: Tarihi ve Toplumsal Anilar. Istanbul: Simurg.

Özkirimli, Umut, and Spyros A. Sofos. 2008. Tormented by History: Nationalism in Greece and Turkey. New York: Columbia University Press. 
Parla, Taha. 1985. The Social and Political Thought of Ziya Gökalp, 1876-1924. Leiden: E.J. Brill.

Perry, Samuel L., and Andrew L. Whitehead. 2015. "Christian Nationalism and White Racial Boundaries: Examining Whites' Opposition to Interracial Marriage.” Ethnic and Racial Studies, no. 1: 1-19.

Poulton, Hugh. 1997. Top Hat, Grey Wolf, and Crescent: Turkish Nationalism and the Turkish Republic. London: C. Hurst \& Co. (Publishers) Ltd.

Roccas, Sonia, and Marilynn B. Brewer. 2002. "Social Identity Complexity." Personality and Social Psychology Review 6 (2): 88-106.

Schmid, K., M. Hewstone, N. Tausch, E. Cairns, and J. Hughes. 2009. “Antecedents and Consequences of Social Identity Complexity: Intergroup Contact, Distinctiveness Threat, and Outgroup Attitudes." Personality \& Social Psychology Bulletin 35 (8): 1085-98.

Smith, Anthony D. 1991. National Identity. Reno: University of Nevada Press.

Sunata, I. Hakki. 2003. Gelibolu'dan Kafkaslar'a: Birinci Dünya Savaşi Hatiralirim. Istanbul: Türkiye Iş Bankasi.

Suny, Ronald Grigor. 2015. "They Can Live in the Desert but Nowhere Else" : A History of the Armenian Genocide. Princeton, N.J.: Princeton University Press.

Tank, Pinar. 2005. "Political Islam in Turkey: A State of Controlled Secularity." Turkish Studies $6(1): 3-19$.

"Türkiye'de Türk Vatandaşlarina Tahsis Edilen Sanat ve Hizmetler Hakkinda Kanun [Law on Professions and Services Allocated to Turkish Citizens in Turkey. Nr, 2007." 1932. In Düstur (Code of Laws), 13:649-50. Third Set. Ankara: Türkiye Büyük Millet Meclisi.

Ulunay, Refii Cevad. 1999. Sürgün Hatiralari (Memoirs of Exile). Edited by Hüsnü Kiliç. Istanbul: Arma Yayinlari.

Uzer, Umut. 2011. "The Genealogy of Turkish Nationalism: From Civic and Ethnic to Conservative Nationalism in Turkey." In Symbiotic Antagonisms Competing Nationalisms in Turkey, edited by Ayse Kadioglu and Emin Fuat Keyman. Salt Lake City: University of Utah Press.

Vryonis, Speros. 2005. The Mechanism of Catastrophe: The Turkish Pogrom of September 6-7, 1955, and the Destruction of the Greek Community of Istanbul. New York, N.Y.: Greekworks.com.

White, Jenny B. 2013. Muslim Nationalism and the New Turks. Princeton: Princeton University Press.

Wimmer, Andreas. 2013. Ethnic Boundary Making: Institutions, Power, Networks. New York: Oxford University Press.

Yavuz, M. Hakan. 1998. "A Preamble to the Kurdish Question: The Politics of Kurdish Identity." Journal of Muslim Minority Affairs 18 (1): 9-18.

Yildirim, Onur. 2006a. Diplomacy and Displacement: Reconsidering the Turco-Greek Exchange of Populations, 1922-1934. New York: Routledge.

- 2006b. "The 1923 Population Exchange: Refugees and National Historiographies in Greece and Turkey." East European Quarterly. 40 (1): 45. 
